\title{
ROS dependent antitumour activity of photo-activated iron(III) complexes of amino acids
}

\author{
S BINITA CHANU ${ }^{\mathrm{a}}$, MD KAUSAR RAZA ${ }^{\mathrm{b}}$, SAMYA BANERJEE ${ }^{\mathrm{c}}$, POOJA RANI MINA ${ }^{\mathrm{d}}$, \\ DULAL MUSIB $^{\mathrm{a}}$ and MITHUN ROY ${ }^{\mathrm{a}, *}$ (D) \\ ${ }^{a}$ Department of Chemistry, National Institute of Technology Manipur, Langol, Imphal, Manipur 795 004, India \\ ${ }^{\mathrm{b}}$ Department of Inorganic and Physical Chemistry, Indian Institute of Science, Bangalore, Karnataka 560012 , \\ India \\ ${ }^{c}$ Department of Chemistry, John Hopkins University, 23400 N. Charles Street, Baltimore, MD 21218, USA \\ ${ }^{\mathrm{d}}$ Department of Molecular Bioprospection, CSIR-Central Institute of Medicinal and Aromatic Plants, Lucknow, \\ Uttar Pradesh 226 015, India \\ E-mail: mithunroy@nitmanipur.ac.in; mithunroy.iisc@ gmail.com
}

MS received 1 October 2018; revised 5 December 2018; accepted 8 December 2018; published online 12 January 2019

\begin{abstract}
Several amino acid-based photo-active monomeric iron(III) complexes of the general formula, $\left[\mathrm{Fe}(\mathrm{L})_{2}\right]^{-}$, where $\mathrm{L}=$ Schiff base ligands (salisalidene arginine, salicylidenetryptophan, 3,5-di-tert-butyl benzalidine arginine and salicylidene tryptophan) were synthesized, characterized and explored for photoactivated anticancer activity to Chang Liver Cells, HeLa and MCF-7 cells. Complexes exhibited remarkable photo-cytotoxicity with $\mathrm{IC}_{50}$ value to the extent of $0.7 \mu \mathrm{M}$ to Chang Liver Cells in visible light and there was a 40-fold enhancement in cytotoxicity in comparison to the cytotoxicity in dark. Complexes were non-toxic to MCF-10A (normal cells) in dark and visible light $\left(\mathrm{IC}_{50}>100 \mu \mathrm{M}\right.$ in dark; $\mathrm{IC}_{50}>80 \mu \mathrm{M}$ in visible light) signifying target-specific nature of the anti-tumour activity of the complexes. Increased ROS concentration, as probed by DCFDA assay, in the cancer cells was responsible for apoptotic cell death. Decarboxylation or phenolate-Fe(III) charge transfer of photo-activated iron(III) complexes generating ${ }^{\bullet} \mathrm{OH}$ radicals (ROS) were responsible for the apoptosis. Overall, the tumour-selective photo-activated anticancer activity of the amino acidbased iron(III) complexes have shown a promising aspect in developing iron-based photo-chemotherapeutics as the next generation PDT agents.
\end{abstract}

Keywords. Iron(III) complexes; amino acid; photocytotoxicity; photo-activation; ROS generation.

\section{Introduction}

Transition metal complexes with a wide range of coordination number and geometry, accessible redox chemistry, 'tunability' of the thermodynamics and kinetics of ligand substitution, electron transfer reaction have emerged as the potential tools for biological and medicinal applications as exemplified by cisdiamino dichloroplatinum(II), a popular anticancer agent that targets genomic DNA. ${ }^{1-5}$ However, systemic side effects including nephrotoxicity, drug resistance, thiol deactivation and lack of target-specificity have limited their clinical applications. Therefore, efforts are needed to find potent, cost-effective and safer cancer treatment

\footnotetext{
*For correspondence

Corrected publication 2019.
}

modalities. Photodynamic therapy (PDT) has emerged as a tumour-specific, non-invasive treatment. ${ }^{6-10}$ It involves simultaneous presence of tumour-localizing photosensitizer (PS), non-toxic red light for activating the PS and molecular oxygen to exhibit anticancer activity. The excited triplet state of the PS transfers its energy to triplet oxygen $\left({ }^{3} \mathrm{O}_{2}\right)$ to generate singlet oxygen $\left({ }^{1} \mathrm{O}_{2}\right)$ to oxidize key cellular macromolecules like proteins, DNA, cell-membrane, etc. leading to tumour ablation. Photofrin ${ }$, a first generation PDT drug, was clinically tested primarily against oesophagal cancer. Due to lack of ideal PS and difficult clinical execution, PDT has yet to gain acceleration in clinical use. Photo-activated coordination compounds exhibiting ligand exchange reaction, an isomerization reaction, intramolecular redox 

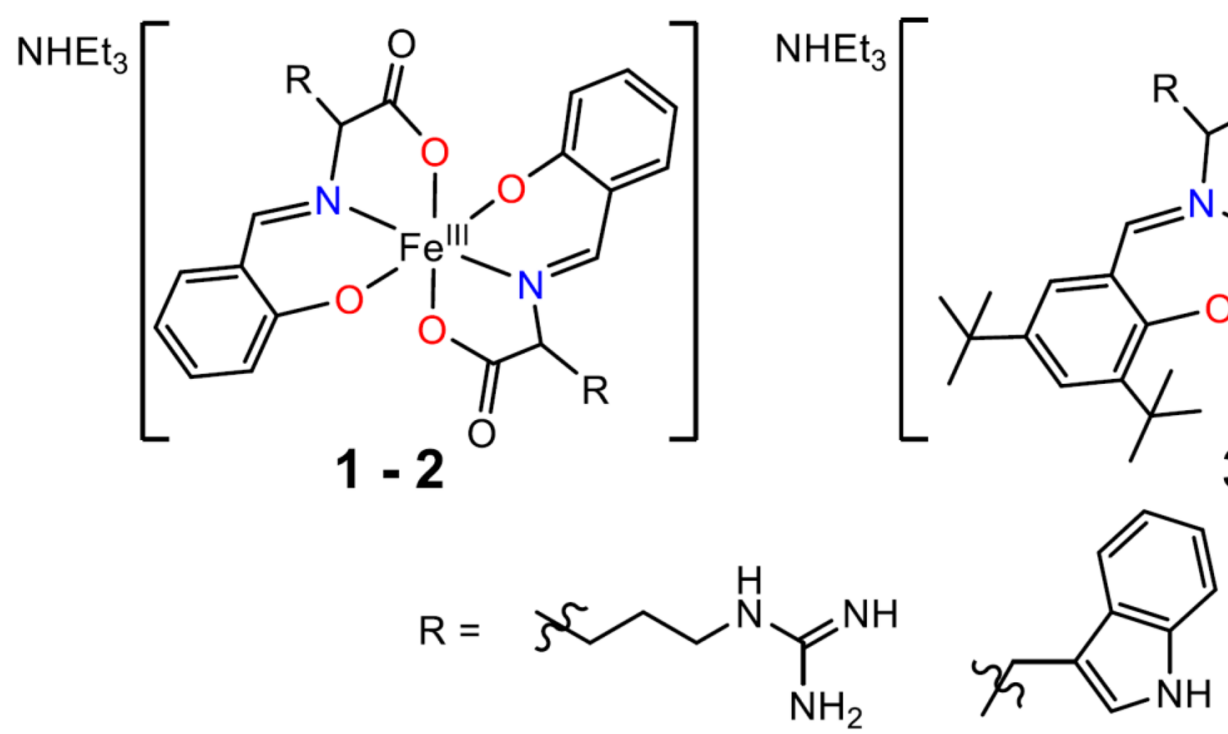

1,3

2,4

Scheme 1. Schematic drawing of the complexes, $\mathrm{NHEt}_{3}\left[\mathrm{Fe}(\mathrm{L})_{2}\right], \mathbf{1}-\mathbf{4}$, where $\mathrm{L}=$ Schiff base ligands of salicylidene arginine and salicylidenetryptophan $(\mathbf{1 , 2}), 3,5$-di-tert-butyl benzalidine arginine and salicylidene tryptophan $(\mathbf{3 , 4})$.

reaction or activating ${ }^{3} \mathrm{O}_{2}$ into ${ }^{1} \mathrm{O}_{2}$ by transferring the energy are suitable for photo-chemotherapeutic applications, as the alternatives for porphyrin-based photosensitizers. ${ }^{11-15}$ Bio-essential and kinetically labile first-row transition metal complexes absorbing light in PDT window (600-700 nm) are, however, preferable for photo-chemotherapeutic applications, Considering greater tissue penetration, longer wavelength absorbing and stable photo-active complexes of biocompatible metal ions like vanadium, cobalt, copper or iron have been explored in PDT window to various cancer cell lines. ${ }^{16-21}$ The present work originated from our interest to develop iron(III)-based complexes for photo-activated chemotherapy by exploring the photo-labile nature of the iron(III)-carboxylates or iron(III)-phenolates on photo-activation at LMCT band generating cytotoxic hydroxyl radical. ${ }^{17,22,23}$ Recently, we explored the photochemistry of the oxo-bridged diiron(III) complexes for photochemotherapeutic applications to various cancer cell lines. ${ }^{24}$ In the present work, we have synthesized several monomeric iron(III) complexes of amino acid-based Schiff base ligands (Scheme 1) to probe photo-activated cytotoxicity to various cancer cells with the mechanistic insight of the chemistry and cell death.

\section{Experimental}

\subsection{Materials and methods}

All reagents and chemicals were procured from HIMEDIA (India), MERCK chemicals (India), Sigma-Aldrich (USA) and used as received without any further purification. The solvents used were purified by standard procedures. ${ }^{25}$ Aqueous solutions were prepared by using double distilled water.

FT-IR spectra were recorded in solid phase using PerkinElmer UATR TWO FT-IR Spectrometer operating from 400 to $4000 \mathrm{~cm}^{-1}$. UV-vis spectrum was recorded on Perkin-Elmer UV/VIS spectrometer. Molar conductivity measurements were done by using a EUTECH INSTRUMENT Control Dynamics (India) conductivity meter. Cyclic voltammetric measurements were made at $25^{\circ} \mathrm{C}$ on a EG\&G PAR model 253 VersaStat potentiostat/galvanostat using a three-electrode setup comprising of a glassy carbon as working, a platinum wire as an auxiliary, and saturated calomel as the reference (SCE) electrode. Tetrabutylammonium perchlorate (TBAP) $(0.1 \mathrm{M})$ was used as supporting electrolyte in dimethylformamide (DMF). ${ }^{22}$ Electrospray ionization mass spectral measurements were done using Esquire 3000 plus ESI (Bruker Daltonics) Q-TOF Mass Spectrometers. Experimental and calculated ESI-MS values for each complex were identical to a significant last figure above the decimal point.

\subsection{Hydroxyl radical generation study (ROS)}

Photo-induced generation of hydroxyl radicals by the iron(III) complexes was studied by UV-visible spectroscopy. In this experiment, benzoic acid $(50 \mu \mathrm{M})$ was initially incubated with $500 \mu \mathrm{M}$ complex in aqueous DMF (10\% v/v) and then photo-activated by using visible light. Hydroxyl radicals generated on photo-activation of Fe(III) complexes were responsible for the formation of salicylic acid which gave a reddish-brown solution of $\mathrm{Fe}(\mathrm{III})$-salicylate complex when methanolic solution of $\mathrm{Fe}\left(\mathrm{NO}_{3}\right)_{3} \cdot 9 \mathrm{H}_{2} \mathrm{O}(100 \mu \mathrm{M})$ was added externally. ${ }^{26,27} \mathrm{UV}$-visible spectra of $\mathrm{Fe}(\mathrm{III})$-salicylate $\left(\lambda_{\max }\right.$, $520 \mathrm{~nm})$ was recorded in the presence of complexes $(50 \mu \mathrm{M})$ 
exposed to visible light $(400-700 \mathrm{~nm})$ for 200 s. Gradual increase in $\mathrm{A}_{520}$ of $\mathrm{Fe}(\mathrm{III})$-salicylate indicated the generation of $\mathrm{OH}$ radical. We plotted the extent of increase of absorbance of $\mathrm{Fe}$ (III)-salicylate against time to correlate the relative photo-activated generation of hydroxyl radicals.

\subsection{Synthesis}

A reported synthetic procedure was used to synthesize amino acid-based Schiff base ligands $\left(\mathbf{L}^{1}-\mathbf{L}^{2}\right) .{ }^{28,29}$ Ligands $\mathbf{L}^{3}$ and $\mathbf{L}^{4}$ were synthesized following same protocol with minor modification and characterized by IR spectroscopy prior to the synthesis of the complexes.

2.3a General synthetic procedure for ligands $\mathbf{L}^{3}$ and $\mathbf{L}^{4}$ : Amino acid (L-arginine, $0.087 \mathrm{~g}, 1.0 \mathrm{mmol}$; L-tryptophan $0.204 \mathrm{~g}, 1.0 \mathrm{mmol}$ ) was dissolved in $1 \% \mathrm{KOH}$ in absolute $\mathrm{MeOH}$ and stirred gently to warming for $30 \mathrm{~min}$. A methanolic solution of 3,5-di-tert-butyl-2-hydroxybenzaldehyde $(0.234 \mathrm{~g}, 1.0 \mathrm{mmol})$ was added and stirred at room temperature for $1 \mathrm{~h}$. The mixture was left for overnight till complete precipitation. The yellow precipitate was collected by filtration, washed with cold ethanol and dried over anhydrous $\mathrm{CaCl}_{2}$. Yield: $60-70 \% \cdot \mathrm{R}_{\mathrm{f}}=0.32\left(\mathbf{L}^{3}\right)$ and $0.45\left(\mathbf{L}^{4}\right)$ in $\mathrm{CH}_{2} \mathrm{Cl}_{2} / \mathrm{MeOH}(5 \% \mathrm{MeOH})$. Typical $\mathrm{C}=\mathrm{N}$ str at $1580 \mathrm{~cm}^{-1}$ was observed for the ligands $\mathbf{L}^{3}$ and $\mathbf{L}^{4}$ indicating Schiff-base ligands.

$2.3 \mathrm{~b}$ General procedure for synthesizing complexes (1-4): Complexes (1-4) were prepared by a general synthetic procedure in which a mixture of $\mathrm{Fe}\left(\mathrm{NO}_{3}\right)_{3} \cdot 9 \mathrm{H}_{2} \mathrm{O}$ $(0.404 \mathrm{~g}, 1 \mathrm{mmol})$ and the Schiff base ligands $\left(\mathrm{H}_{2} \mathrm{~L}^{1}, 0.558 \mathrm{~g}\right.$; $\mathrm{H}_{2} \mathrm{~L}^{2}, 0.408 \mathrm{~g} ; \mathrm{H}_{2} \mathrm{~L}^{3}, 0.70 \mathrm{~g} ; \mathrm{H}_{2} \mathrm{~L}^{4}, 0.841 \mathrm{~g}$ ) was refluxed for $3 \mathrm{~h}$ in $30 \mathrm{~mL} \mathrm{MeOH}$ to deep purple solution in the presence of $1 \mathrm{~mL}$ of triethylamine. Complexes were precipitated from ethyl acetate. The reddish-purple precipitate was washed with cold ethanol and dried over vacuum. Yield: 50-70\%.

Anal. Calc. for $\mathrm{C}_{32} \mathrm{H}_{48} \mathrm{~N}_{9} \mathrm{O}_{6} \mathrm{Fe}(1)$ : Yield: 57\%; C, 54.09; H, 6.81; N, 17.74. Found: C, 53.85; H, 6.75; N, 17.67. Molar conductance $\left(\Lambda_{\mathrm{M}}, \mathrm{Sm}^{2} \mathrm{~mol}^{-1}\right)$ in DMF- $\mathrm{H}_{2} \mathrm{O}(10 \% \mathrm{v} / \mathrm{v}$ DMF: $\mathrm{H}_{2} \mathrm{O}$ ) at $30^{\circ} \mathrm{C}: 110$; FT-IR (KBr phase), $\mathrm{cm}^{-1}: 3205 \mathrm{br}$ $\left(\mathrm{H}_{2} \mathrm{O}\right), 1620 \mathrm{~s}\left(\mathrm{C}=\mathrm{O}_{\mathrm{str}}\right), 1377 \mathrm{~s}, 1155 \mathrm{w}\left(\mathrm{C}=\mathrm{N}_{\mathrm{str}}\right), 566 \mathrm{w}$. (br, broad; vs, very strong; s, strong; m, medium; w, weak). (br, broad; w, weak; m, medium; s, strong). Q-TOF ESI MS $(\mathrm{MeOH}): \mathrm{m} / \mathrm{z} 610.1951\left[\mathrm{MH}_{2}\right]^{+}$. UV-visible in DMF-H $\mathrm{H}_{2} \mathrm{O}$ $\left(10 \%\right.$ v/v DMF: $\left.\mathrm{H}_{2} \mathrm{O}\right)\left[\lambda_{\max }, \mathrm{nm}\left(\varepsilon \times 10^{-4}, \mathrm{~L} \mathrm{~mol}^{-1} \mathrm{~cm}^{-1}\right)\right]$ : 485 (648), 418 (725).

Anal. Calc. for $\mathrm{C}_{42} \mathrm{H}_{44} \mathrm{~N}_{5} \mathrm{O}_{6} \mathrm{Fe}$ (2): Yield: 65\%; C, 65.46; H, 5.75; N, 9.09; Found C, 65.26; H, 5.59; N, 9.01. Molar conductance $\left(\Lambda_{\mathrm{M}}, \mathrm{Sm}^{2} \mathrm{~mol}^{-1}\right)$ in DMF- $\mathrm{H}_{2} \mathrm{O}$ (10\% v/v DMF: $\left.\mathrm{H}_{2} \mathrm{O}\right)$ at $30^{\circ} \mathrm{C}: 105$. FT-IR ( $\mathrm{KBr}$ phase), $\mathrm{cm}^{-1}$ : 3384s $\left(\mathrm{H}_{2} \mathrm{O}\right), 3040 \mathrm{br}(\mathrm{NH}), 1610 \mathrm{~s}\left(\mathrm{C}=\mathrm{O}_{\mathrm{str}}\right), 1367 \mathrm{~s}$, 1170s $\left(\mathrm{C}=\mathrm{N}_{\mathrm{str}}\right), 736 \mathrm{~s}, 523 \mathrm{~s}$. Q-TOF ESI MS: $\mathrm{m} / \mathrm{z} 670.0283$ $\left[\mathrm{MH}_{2}\right]^{+}$. UV-visible in DMF- $\mathrm{H}_{2} \mathrm{O}\left(10 \% \mathrm{v} / \mathrm{v}\right.$ DMF: $\left.\mathrm{H}_{2} \mathrm{O}\right)$ $\left[\lambda_{\max }, \mathrm{nm}\left(\varepsilon \times 10^{-4}, \mathrm{~L} \mathrm{~mol}^{-1} \mathrm{~cm}^{-1}\right)\right]: 493(725), 414(960)$.

Anal. Calc. for $\mathrm{C}_{48} \mathrm{H}_{80} \mathrm{~N}_{9} \mathrm{O}_{6} \mathrm{Fe}$ (3): Yield: 51\%; C, 61.66; H, 8.62; N, 13.48; Found: C, 61.49; H, 8.54; N,
13.39. Molar conductance $\left(\Lambda_{\mathrm{M}}, \mathrm{Sm}^{2} \mathrm{~mol}^{-1}\right)$ in DMF- $\mathrm{H}_{2} \mathrm{O}$ $\left(10 \%\right.$ v/v DMF: $\left.\mathrm{H}_{2} \mathrm{O}\right)$ at $30^{\circ} \mathrm{C}: 100$. FT-IR ( $\mathrm{KBr}$ phase), $\mathrm{cm}^{-1}$ : $3331 \mathrm{br}\left(\mathrm{H}_{2} \mathrm{O}\right), 2950 \mathrm{br}(\mathrm{NH}), 1618 \mathrm{~s}\left(\mathrm{C}=\mathrm{O}_{\text {str }}\right), 1528 \mathrm{w}$, $1428 \mathrm{w}, 1360 \mathrm{w}, 1253 \mathrm{w}, 1170 \mathrm{~s}\left(\mathrm{C}=\mathrm{N}_{\mathrm{str}}\right)$. Q-TOF ESI MS: $\mathrm{m} / \mathrm{z} 834.4455\left[\mathrm{MH}_{2}\right]^{+}$.UV-visible in DMF- $\mathrm{H}_{2} \mathrm{O}(10 \% \mathrm{v} / \mathrm{v}$ DMF: $\left.\mathrm{H}_{2} \mathrm{O}\right)\left[\lambda_{\max }, \mathrm{nm}\left(\varepsilon \times 10^{-4}, \mathrm{~L} \mathrm{~mol}^{-1} \mathrm{~cm}^{-1}\right)\right]: 526(379)$, 423 (1114).

Anal. Calc. for $\mathrm{C}_{58} \mathrm{H}_{76} \mathrm{~N}_{5} \mathrm{O}_{6} \mathrm{Fe}(4)$ : Yield: $72 \%$; C, 70.01; H, 7.70; N, 7.04; Found: C, 69.69; H, 7.65; N, 6.93. Molar conductance $\left(\Lambda_{\mathrm{M}}, \mathrm{Sm}^{2} \mathrm{~mol}^{-1}\right)$ in DMF- $\mathrm{H}_{2} \mathrm{O}(10 \% \mathrm{v} / \mathrm{v}$ DMF: $\mathrm{H}_{2} \mathrm{O}$ ) at $30^{\circ} \mathrm{C}: 95$. FT-IR (KBr phase), $\mathrm{cm}^{-1}: 3231 \mathrm{br}$ $\left(\mathrm{H}_{2} \mathrm{O}\right), 2988 \mathrm{~m}, 2942 \mathrm{~m}(\mathrm{C}-\mathrm{H}), 2608 \mathrm{~s}\left(\mathrm{COO}^{-}\right), 2502 \mathrm{~s}, 1618 \mathrm{~s}$ $\left(\mathrm{C}=\mathrm{O}_{\text {str }}\right), 1443 \mathrm{~s}, 1140 \mathrm{~s}\left(\mathrm{C}=\mathrm{N}_{\text {str }}\right), 737 \mathrm{~m}, 553 \mathrm{~m} . \mathrm{Q}-\mathrm{TOF}$ ESI MS: $\mathrm{m} / \mathrm{z} 894.4076\left[\mathrm{MH}_{2}\right]^{+}$. UV-visible in DMF- $\mathrm{H}_{2} \mathrm{O}(10 \%$ v/v DMF: $\left.\mathrm{H}_{2} \mathrm{O}\right)\left[\lambda_{\max }, \mathrm{nm}\left(\varepsilon \times 10^{-4}, \mathrm{~L} \mathrm{~mol}^{-1} \mathrm{~cm}^{-1}\right)\right]: 520$ (302), 440 (221).

\subsection{Biological assay}

Experimental details of Cell viability assay, ROS generation are provided in the Supplementary section.

\section{Results and Discussion}

\subsection{Synthesis}

All the four new amino acid-based binary complexes of the formulation $\mathrm{Et}_{3} \mathrm{NH}\left[\mathrm{Fe}(\mathrm{L})_{2}\right]$ were prepared by general synthetic procedure in which methanolic solution of $\mathrm{Fe}\left(\mathrm{NO}_{3}\right)_{3} \cdot 9 \mathrm{H}_{2} \mathrm{O}$ was refluxed with the methanolic solution of amino acid-based Schiff base ligands $\left(\mathbf{L}^{1}-\mathbf{L}^{4}\right)$ in the presence of stoichiometric amount of triethylamine $\left(\mathrm{Et}_{3} \mathrm{~N}\right)$. Complexes were precipitated as a reddish-brown powder on the addition of ethyl acetate. Dried complexes were used for further characterization, analytical studies and photo-activated cytotoxic investigations. The purity of the complexes was determined by elemental analysis ( $\mathrm{C}, \mathrm{H}, \mathrm{N}$ analysis) before characterization and other studies.

\subsection{Solubility and stability}

Complexes (1-4) were soluble in aqueous dimethylformamide (10\% v/v, DMF), DMF and dimethyl sulfoxide (DMSO). Stability of the complexes was determined by UV-visible spectral measurements in which spectral traces were recorded in different time intervals till $72 \mathrm{~h}$ in DMF: $\mathrm{H}_{2} \mathrm{O}(10 \%$ DMF v/v). We observed no change in UV-visible spectra of the complexes in aqueous DMF indicating the stability of the complexes for biological studies. However, UV-A $(365 \mathrm{~nm})$ light had a significant effect on the complexes in aqueous DMF. 


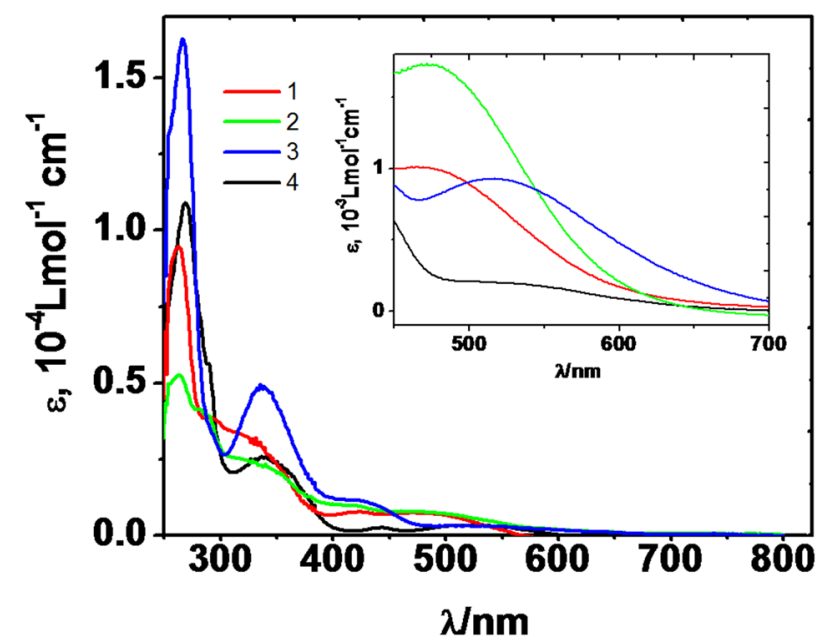

Figure 1. The UV-visible spectrum of the complexes 1-4 in $\mathrm{DMF}-\mathrm{H}_{2} \mathrm{O}\left(10 \% \mathrm{v} / \mathrm{v} \mathrm{DMF}: \mathrm{H}_{2} \mathrm{O}\right)$ with the inset showing their $\mathrm{d}-\mathrm{d}$ bands.

\subsection{Characterization and general aspects}

Negatively charged complexes were 1:1 electrolyte as evident from the molar conductance data typically in the range 95-115 $\mathrm{Sm}^{2} \mathrm{~mol}^{-1}$ determined in aqueous-DMF (10\% v/v DMF). ${ }^{30}$ Complexes were characterized by the molecular ion peak as $\left[\mathrm{MH}_{2}\right]^{+}$, where $\mathrm{M}$ was the molecular ion, in Q-TOF ESI mass spectra determined in $\mathrm{MeOH}$ (Figures S1-S4, Supplementary Information). Strong $\mathrm{C}=\mathrm{N}_{\text {str }}$ was observed at $\sim 1500 \mathrm{~cm}^{-1}$ in the IR spectra of the complexes (Figure S5, Supplementary Information). ${ }^{31}$ Complexes exhibited a broadband with $\lambda_{\max }$ in the range $480-550 \mathrm{~nm}$, assignable to typical phenolate $\left(\mathrm{p}_{\pi}\right)$-to-iron $(\mathrm{III})\left(\mathrm{d}_{\pi *}\right)$ or carboxylate $\left(\mathrm{p}_{\pi}\right)$-to-iron(III) $\left(\mathrm{d}_{\pi *}\right)$ charge-transfer transition in DMF- $\mathrm{H}_{2} \mathrm{O}$ (10\% DMF v/v) (Figure 1). ${ }^{22-24}$ Other ligand-centred (LC) bands for the complexes were observed at $<400 \mathrm{~nm}$. The LMCT band is broad extending to the PDT window that enabled us to use visible light (400-800 $\mathrm{nm}$ ) for photocytotoxicity of the complexes. Complexes $(\mathbf{2 , 4})$ showed quasi-reversible cyclic-voltammetric response at $0.00 \mathrm{~V}$ and $0.04 \mathrm{~V}$, respectively, for the $\mathrm{Fe}(\mathrm{III}) / \mathrm{Fe}(\mathrm{II})$ couple in DMF containing $0.1 \mathrm{M}$ TBAP as supporting electrolyte. The negative reduction potential of the redox couple indicated facile redox chemistry of the complexes rendering them suited for photo-chemo-therapeutic applications (Figure S6, Supplementary Information).

\subsection{DFT calculations and optimized geometry}

Optimized geometry and the corresponding energetics of the complexes (1-4) was determined by using unrestricted B3LYP density functional theory. ${ }^{32}$ The optimized energy of all complexes (1-4) are $\mathbf{1}(-2023$ a.u.), $\mathbf{2}(-2184$ a.u.), $\mathbf{3}(-2453$ a.u.) and $\mathbf{4}$ (-2648 a.u) (Figure 2). The optimized energy of the complexes is lower than their corresponding ligands, $\mathrm{L}^{1}$ (-950.97 a.u.), $\mathrm{L}^{2}$ (-1030.36 a.u.), $\mathrm{L}^{3}(-1263.87$ a.u.) and $\mathrm{L}^{4}(-1343.74$ a.u.) (Figure S10, Supplementary Information) which indicated the formation stable complexes (2-4). We have determined the energies of HOMO and LUMO of the respective complexes. Larger energy gap in HOMO and LUMO indicated the thermodynamic stability of the complexes.

3.4a Photo-cytotoxicity assay: Ability of mitochondrial dehydrogenases in the viable cells to cleave the tetrazolium rings of 3-(4,5-dimethylthiazol-2-yl)-2,5diphenyltetrazolium bromide (MTT) forming dark violet membrane impermeable crystals of formazan was explored to probe cytotoxicity of the complexes in vitro to Chang Liver Cell, HeLa (human cervical carcinoma), MCF-7 (human breast carcinoma) and normal breast cells line (MCF-10A) in the dark or under photoilluminated condition using visible light $(400-700 \mathrm{~nm}$, $10 \mathrm{~J} \mathrm{~cm}^{-2}$ ) (Table 1, Figure 3, Figure S7). ${ }^{22}$ MCF-10a cell line was chosen as a control cell line to probe the tumour-specificity of the complexes. ${ }^{33}$ Cells were treated with the complexes in dose-dependent manner and the $\mathrm{IC}_{50}$ values were obtained by the non-regression analysis of the dose-response plot for the complexes and the same are presented in Table 1.

Complexes (1-4) were non-toxic to $\mathrm{HeLa}$ and MCF-7 cells in dark $\left(\mathrm{IC}_{50} \sim 60-90 \mu \mathrm{M}\right)$, while they are moderately toxic $\left(\mathrm{IC}_{50} \sim 40 \mu \mathrm{M}\right)$ to Chang Liver Cells although the difference in cytotoxicity behavior in different cell lines are not clearly known. We observed the remarkable effect of visible light on the cell viability of the cancer cells treated with the complexes $\left(\mathrm{IC}_{50} \sim 6-20 \mu \mathrm{M}\right)$. However, complexes (1-4) were enormously cytotoxic to Chang Liver Cells with an approximate $\mathrm{IC}_{50}$ value of $1.0 \mu \mathrm{M}$. The photocytotoxicity index (PCI), which may be defined as the ratio of $\mathrm{IC}_{50}$ values in dark and light, of the complexes (1-4) in Chang Liver Cells are in the range 24-56. Complex 4 with photo-active indole moiety exhibited highest photo-cytotoxicity index. However, the photocytotoxicity index of the complexes in HeLa and MCF-7 cells were $<15$, with the complex 4 exhibited highest among the complexes. Level of toxicity of the complexes in normal cells (MCF-10A) in dark and light was significantly low $\left(\mathrm{IC}_{50}\right.$ in dark, $>100 \mu \mathrm{M}$; $\mathrm{IC}_{50}$ in light $\sim 90 \mu \mathrm{M}$ ) revealing state of the art of the iron-based compounds as targeted photo-chemotherapy. Lower toxicity of the complexes in MCF-10A cells may 


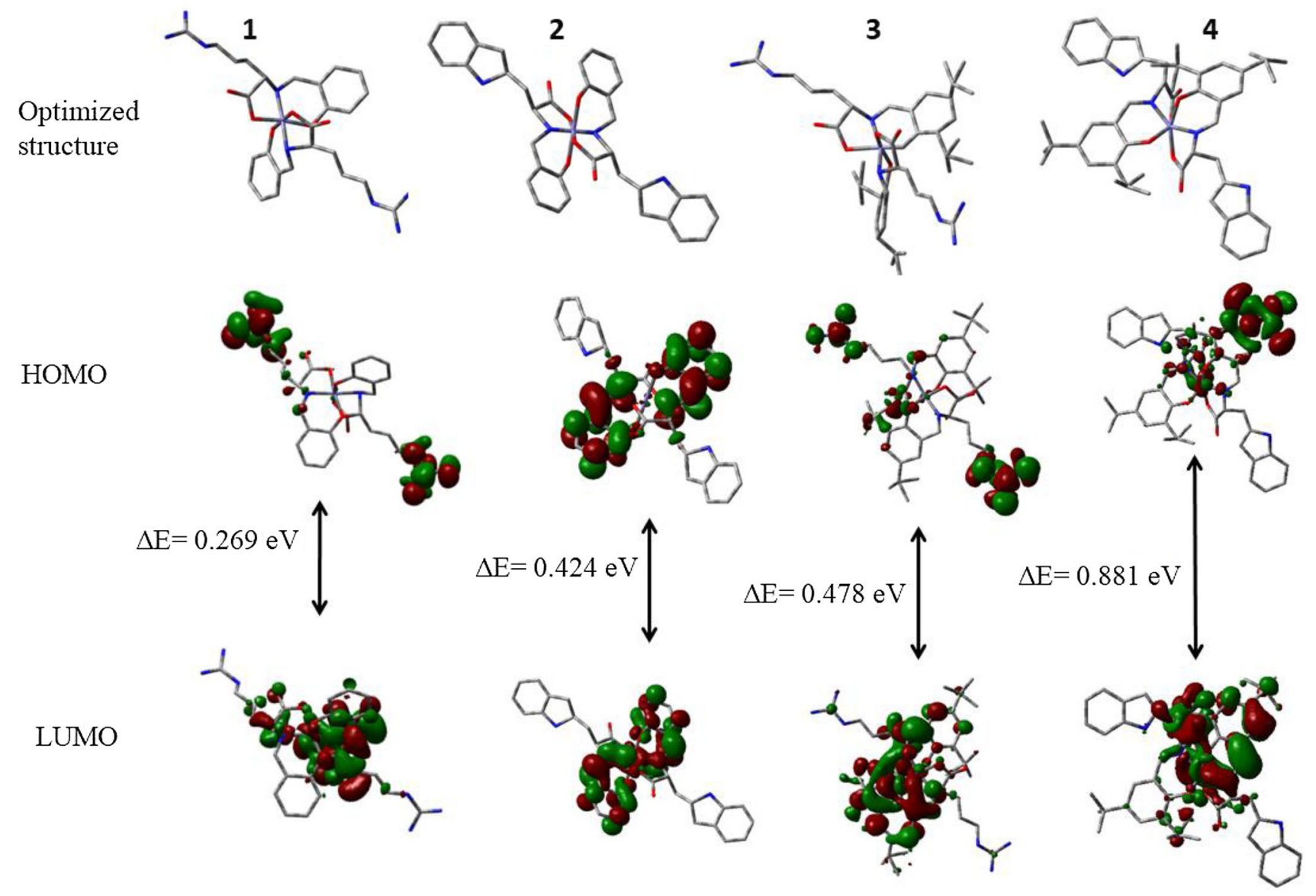

Figure 2. Energy-minimized structures and HOMO/LUMO of all complexes (1-4).

be due to the natural efflux mechanism in the normal cells or could be due to the reduced concentration of ROS. Ligands $\left(\mathbf{L}^{1}-\mathbf{L}^{4}\right)$ and $\mathrm{Fe}\left(\mathrm{NO}_{3}\right)_{3} \cdot 9 \mathrm{H}_{2} \mathrm{O}$ were almost non-toxic to $\mathrm{HeLa}$ cells excluding any possibility of the artefact as the involvement of only ligands or the $\mathrm{Fe}^{3+}$ salt in photo-cytotoxicity. It was the ligands in $\mathrm{Fe}$ (III)-bound form, has shown photocytotoxicity. Preferential exposure of light to tumours only in PDT has led the method to be tumour-specific. In the present case, we compared the cytotoxicity of the complexes to the cancer cells in light and to the normal cells in dark mimicking the condition in PDT. We observed remarkable differences in cytotoxicity for the complexes considering the protocol of clinical exercise of PDT and this could be of paramount importance in developing iron(III)-based next generation photochemotherapeutics.

\subsection{Intracellular Reactive Oxygen Species (ROS) generation}

Enhanced cytotoxicity of the photo-activated complexes (1-4) in cancer cells compared to the normal cells might be due to the enhanced generation of ROS. The intracellular ROS generation in MCF-7 cells treated with complex 4 on photo-exposure was studied using non-polar cell permeable $2^{\prime}, 7^{\prime}$-dichlorofluorescein diacetate (DCFH-DA) dye (Figure 4). The dye which is cleaved by the intracellular esterase is converted into highly fluorescent $2^{\prime}, 7^{\prime}$-dichlorofluorescein (DCF) on oxidation by intracellular ROS or ROS generated in situ, emitting green light. Intracellular ROS generation was probed in our present study by flow cytometric analysis (FACS) on MCF-7 cells using DCFH-DA dye. ${ }^{34}$ Shift in fluorescence intensity of the MCF-7 cells treated with the complexes gave us the measure of the intensity of ROS generation. A greater shift signified a higher amount of oxidized DCF and thus greater ROS generation.

Nature of ROS was probed by the $0.8 \%$ agarose gel electrophoresis where we have confirmed the photooxidation of SC pUC18DNAin UV-A light (365 nm) (Figure S8, Supplementary Information). Complexes (1-4) were able to cleave SC DNA to the extent of $60 \%$ into the nicked circular (NC) form. However, we observed a significant reduction in the cleavage of 


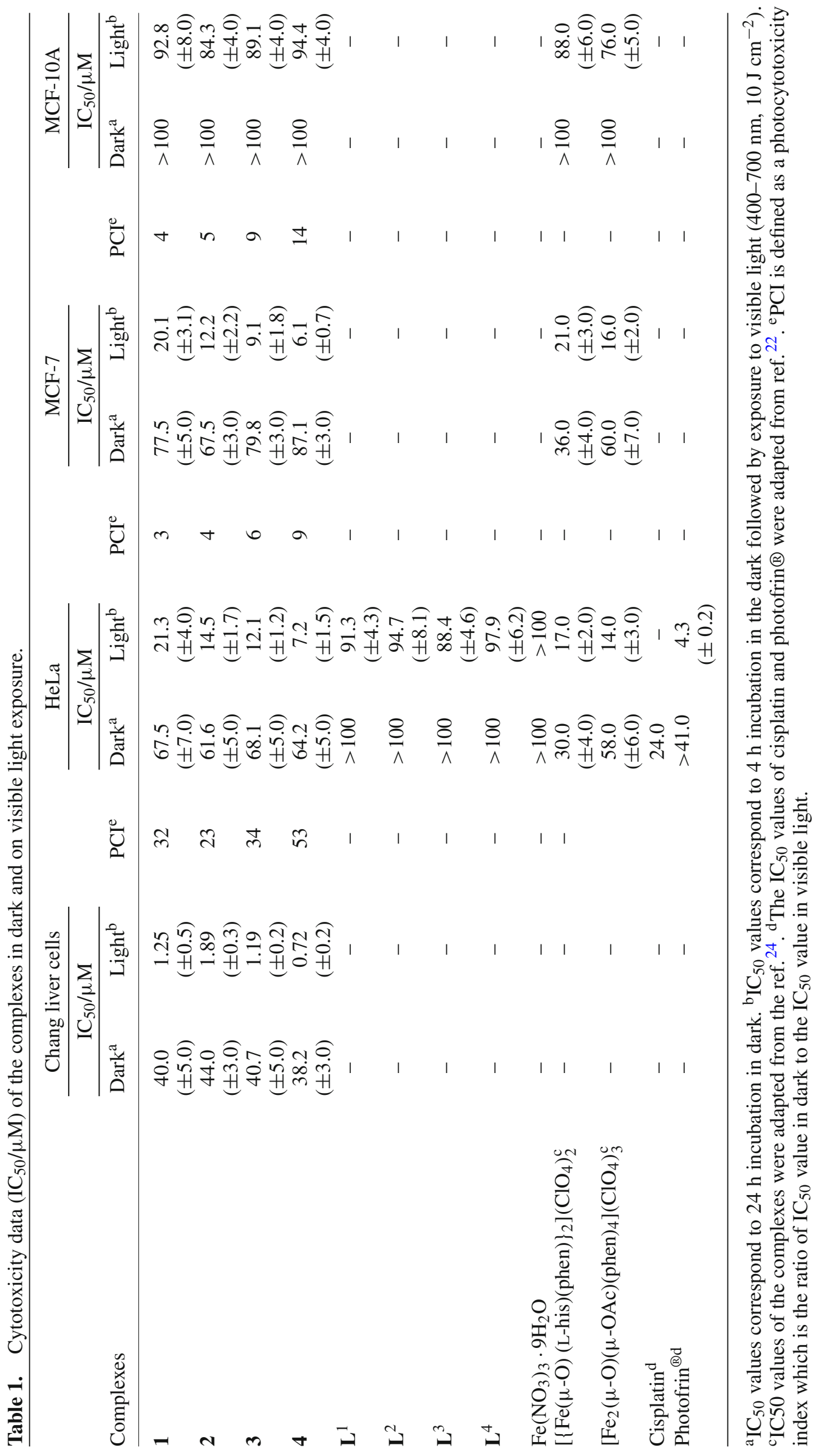



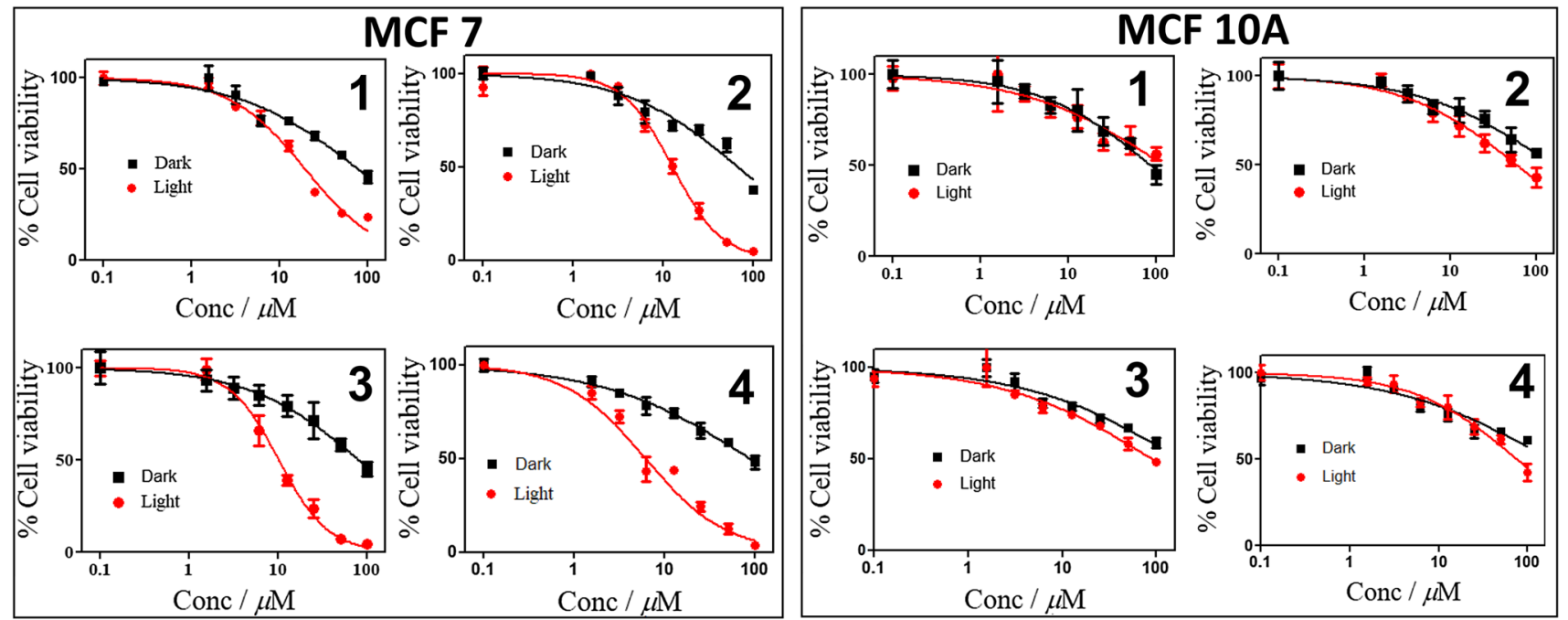

Figure 3. Cell viability (MTT assay) plots showing cytotoxicity of the iron complexes (1-4) to MCF-7 and MCF-10a cells in dark (black squares) and in the presence of visible light (red symbols, 400-700 nm, $10 \mathrm{~J} \mathrm{~cm}^{-2}$ ). MCF-7 and MCF-10a cells: visible light exposure (400-700 nm, $10 \mathrm{~J} \mathrm{~cm}^{-2}$ ). The black symbols denote cells treated with the complexes in dark whereas the red symbols denote cells treated with the complexes in presence of visible light.

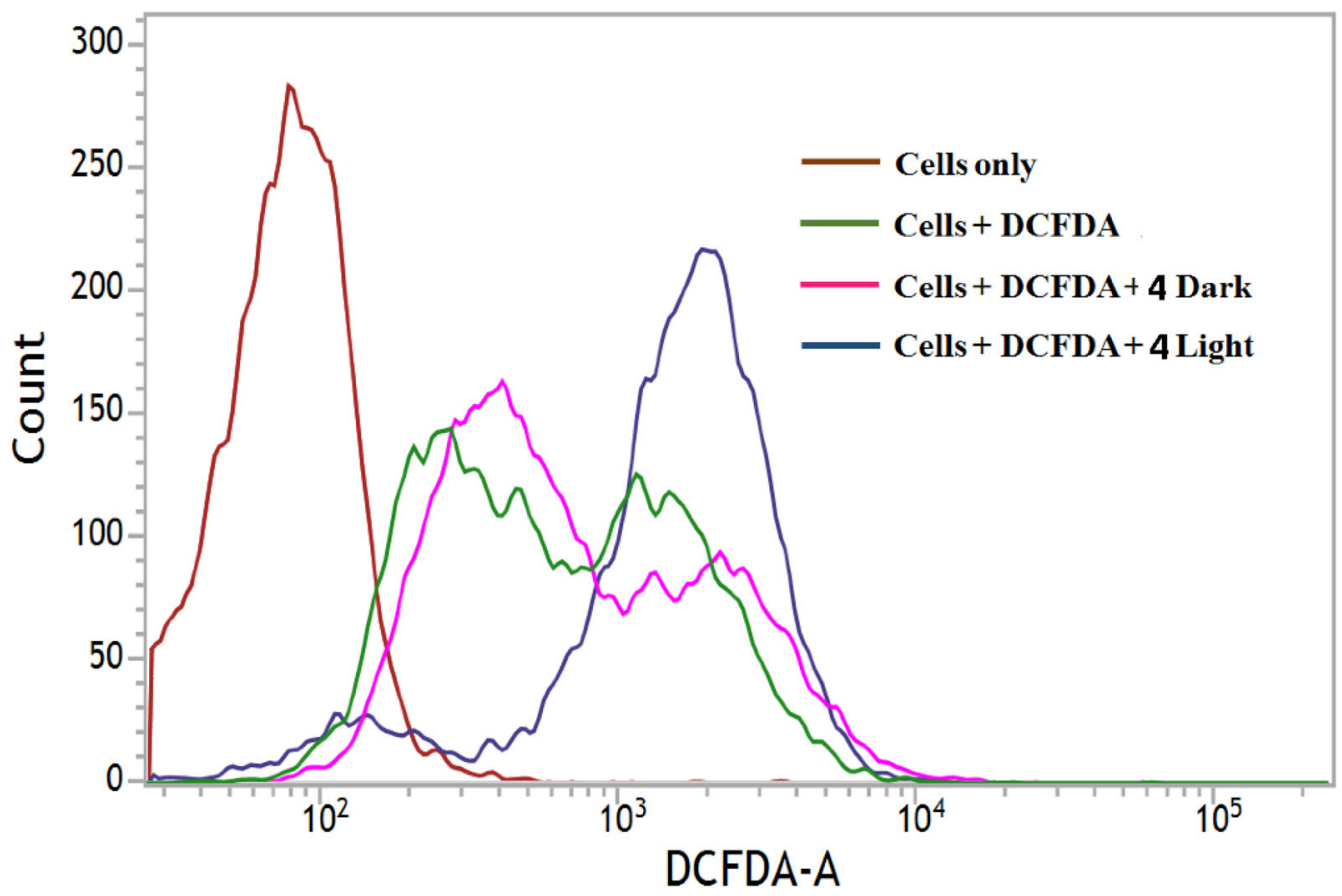

Figure 4. The shift in fluorescence band of DCFH-DA of MCF-7 cells treated with the complex 4 in dark and in visible light $\left(400-700 \mathrm{~nm}, 10 \mathrm{~J} \mathrm{~cm}^{-2}\right)$ indicating the extent of ROS generation by the complexes.

SC pUC19 DNA in the presence of hydroxyl radical $\left({ }^{\bullet} \mathrm{OH}\right)$ radical scavengers like DMSO, KI and mannitol indicating generation of hydroxyl radical (Figure S10, Supplementary Information) as the oxidant responsible for DNA cleavage, when the complex 4 was photoactivated. $^{35}$

\subsection{UV-visible spectral probe for hydroxyl radical} $\left({ }^{\bullet} \mathrm{OH}\right)$ generation

Later we probed the photo-activated generation of hydroxyl radical $\left({ }^{\bullet} \mathrm{OH}\right)$ by photochemical hydroxylation of benzoic acid into salicylic acid. ${ }^{26,27}$ Photo-activated 


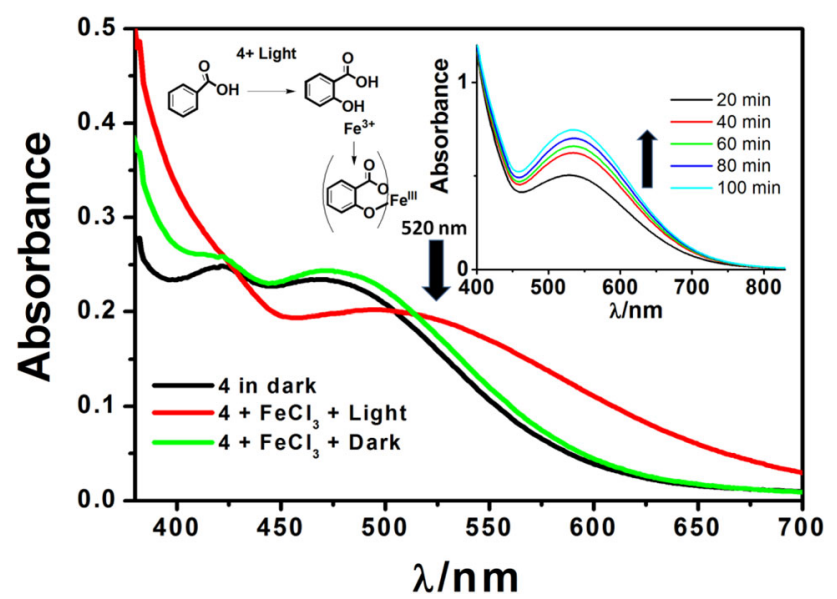

Figure 5. Studies on the generation of hydroxyl radical when complex 4 was photo-activated in visible light (400-700 $\mathrm{nm}, 10 \mathrm{~J} \mathrm{~cm}^{-2}$ ). The inset figure shows the changes in the spectral traces of the complex $\mathbf{4}$ with exposure to the UV-A light for different intervals.

complexes those were able to generate hydroxyl radical, efficiently transform benzoic acid into salicylic acid which form $\mathrm{Fe}(\mathrm{III})$-salicylate complex on external addition of a methanolic solution of $\mathrm{Fe}\left(\mathrm{NO}_{3}\right)_{3} \cdot 9 \mathrm{H}_{2} \mathrm{O}$. Formation of $\mathrm{Fe}(\mathrm{III})$-salicylate was probed by UVvisible spectroscopy with the intense band (LMCT) at $520 \mathrm{~nm}$. The intensity of the band was observed to be increased with respect to the UV light irradiation time (Figure 5, Figure S9, Supplementary Information).

For complex 4, although, we observed the appearance of new bands at $550 \mathrm{~nm}$ instead of typical Fe(III)salicylate band at $520 \mathrm{~nm}$. Complex 4 could generate an excess amount of $\bullet \mathrm{OH}$ radical leading to the formation of catechol and $\mathrm{Fe}$ (III)-catecholate has typical $\lambda_{\max }>$ $550 \mathrm{~nm} .{ }^{36}$ Generation hydroxyl radical $\left(\bullet^{\circ} \mathrm{OH}\right)$ as ROS from the photo-activated complexes can be explained according to the Scheme 2.

Photo-activation at the phenolate to $\mathrm{Fe}$ (III) or carboxylate to Fe(III) LMCT band localized in 450-550 $\mathrm{nm}$ could lead to the charge transfer from phenolate to $\mathrm{Fe}$ (III) or photodecarboxylation. Either way in situ generated iron(II) is readily susceptible for Fenton type reaction with molecular oxygen to generate hydroxyl $\left(\bullet^{\bullet} \mathrm{OH}\right)$ radical. ${ }^{23,24}$ Level of hydroxyl radical generation accounted for the relative order of photocytotoxicity of the complexes $(\mathbf{1}-\mathbf{4})$. The presence of $t$ $\mathrm{Bu}$ group in the complex 4 might be responsible in facilitating rapid charge transfer from phenolate $\rightarrow \mathrm{Fe}$ (III) on photo-activation and stabilizing the resulting phenolate radical, $\mathrm{Fe}(\mathrm{II})$ as well. This resulted in the generation of enhanced hydroxyl radical $\left({ }^{\bullet} \mathrm{OH}\right)$ and accounted for higher photo-cytotoxicity of the complex 4.

\subsection{Apoptosis}

To investigate the mode of photo-induced cell death, Annexin-V-FITC/PI assay was performed with MCF7 cell line (Figure 6) ${ }^{37}$ This assay was based on the dual staining by annexin V-FITC (fluorescein isothiocyanate) and the DNA binding dye propidium iodide (PI). Cells in the early apoptosis stage are identified as a population in Q1-LR, necrotic cells population will be identified in Q1-UL. The population in Q1-UR represents cells in the late apoptotic stage. The MCF-7 cells

\section{Phenolate- $O$-Fe(III) LMCT}

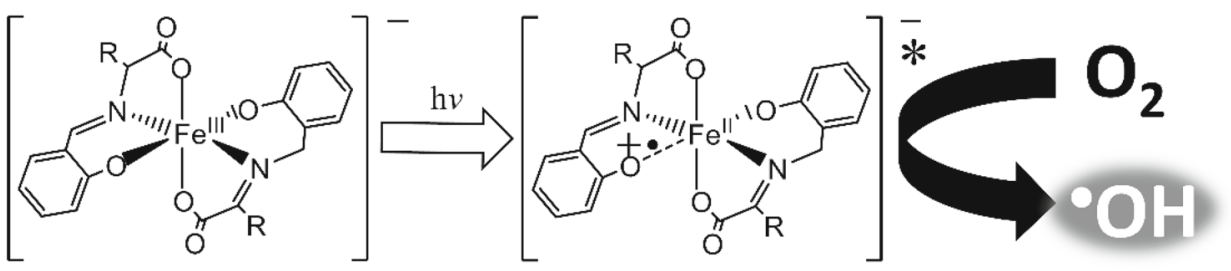

Iron(III) Complex

\section{Carboxylate- $O$-Fe(III) LMCT}

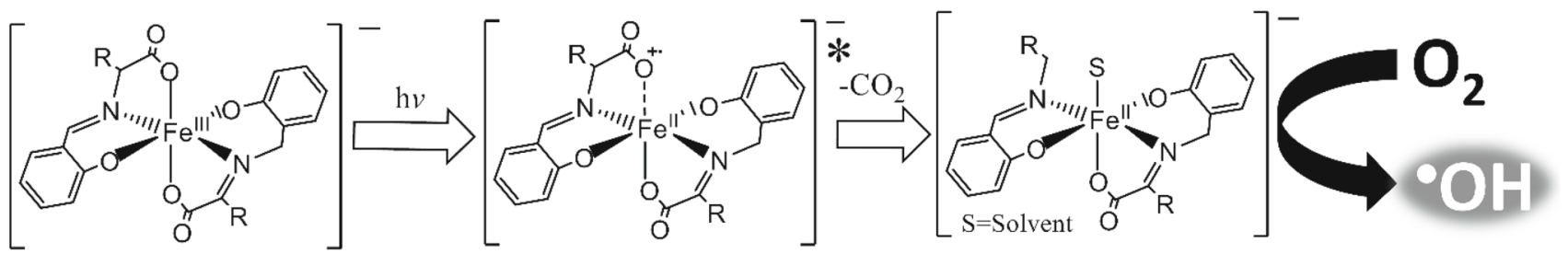

Iron(III) Complex

Scheme 2. The proposed mechanism of photo-activated generation of hydroxyl radical by the complexes (1-4). 


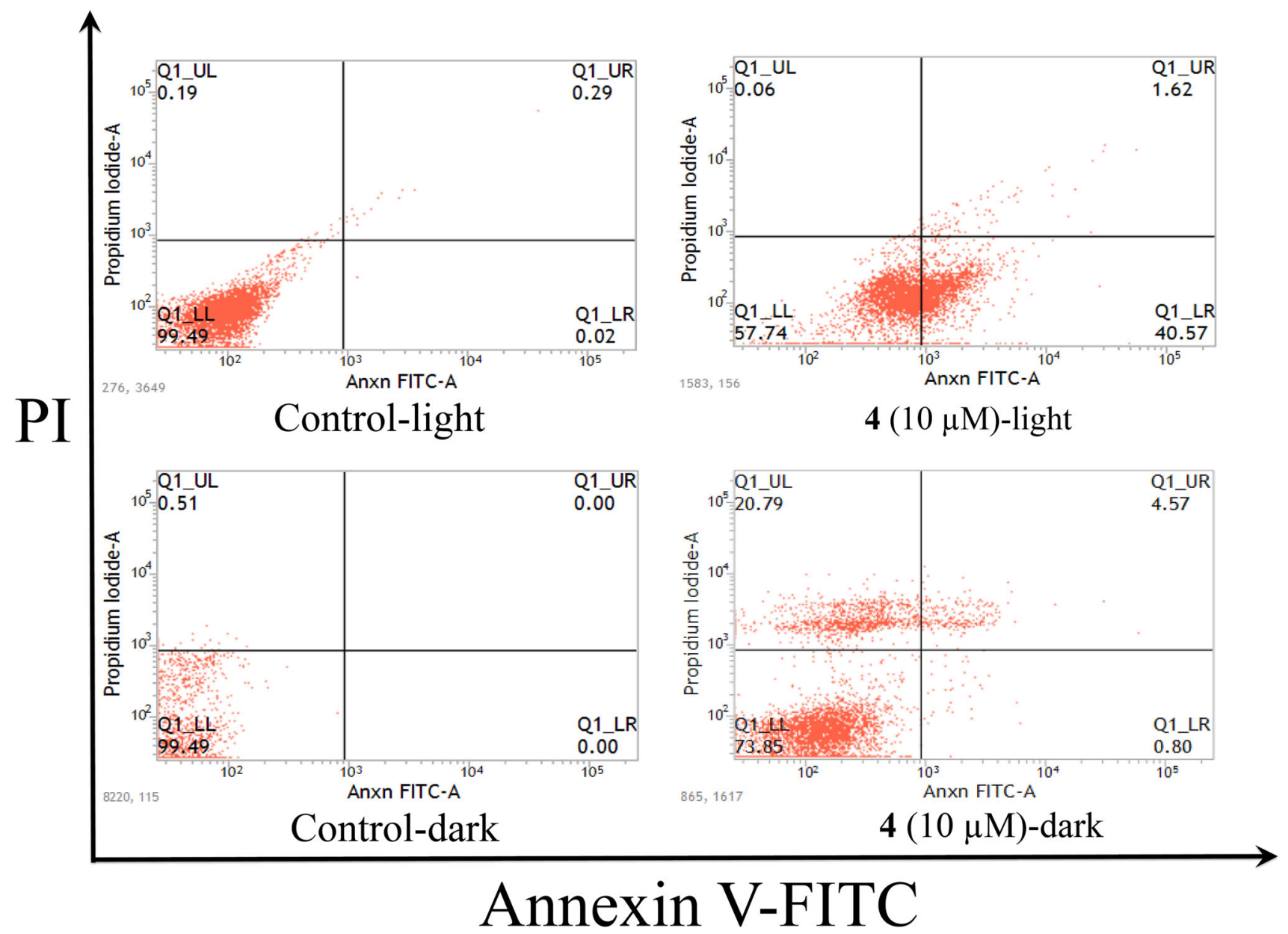

Figure 6. Annexin V-FITC/PI coupled to flow cytometry analysis showing apoptosis induced by complex $4(10 \mu \mathrm{M})$ in the presence of visible light $\left(400-700 \mathrm{~nm}, 10 \mathrm{~J} \mathrm{~cm}^{-2}\right)$.

were treated with complex $4(10 \mu \mathrm{M})$ followed by $1 \mathrm{~h}$ photo-irradiation with $400-700 \mathrm{~nm}$ light and $4 \mathrm{~h}$ post photo-irradiation incubation. Around $42 \%$ populations of the cells were in apoptotic stage (Q1-LR+ Q1-UR) without any significant necrotic population. In the dark, however, the complex induced about $20 \%$ necrotic cell deaths. Overall, this assay suggests an apoptotic mechanism of photo-induced cell death by the complex 4 .

\section{Conclusions}

In summary, we have explored the photo-activated antitumour activity of selected monomeric amino-acidbased iron(III) complexes by modulating intracellular levels of ROS when exposed to the visible light. The cytotoxicity was purely ROS dependent. Complexes when photo-activated at their broad LMCT band $(400-600 \mathrm{~nm})$, hydroxyl $\left({ }^{\circ} \mathrm{OH}\right)$ radical was generated via photo-redox mechanism (Type-I photoprocess) and enhanced concentration of ROS might have knocked down the mitochondrial redox cascades which led to the apoptosis. Cytotoxicity of the complexes was remarkably tumour-specific leaving normal cells almost unaffected. Therefore, the present study has ended up with a considerable scope to explore iron(III) complexes further for in vivo applications and extensive testing towards the clinical applications of photodynamic therapy (PDT) in lieu of current drugs.

\section{Supplementary Information (SI)}

SI has details on biological assays like cell-viability assay, studies in intracellular ROS generation, Figures related to Q-TOF ESI mass spectra, solid-phase IR, Cyclic voltammetry, MTT plots of the ligands $\left(\mathrm{L}^{1}-\mathrm{L}^{4}\right), 0.8 \%$ agarose gel electrophoresis and studies on hydroxyl radical generation. Supplementary Information is available at www.ias.ac.in/ chemsci.

\section{Acknowledgements}

We thank the National Institute of Technology, Manipur for providing a research facility to carry out the work. We gratefully thank the Board of Research in Nuclear Science (BRNS), Mumbai (37(2)/14/18/2017-BRNS) and Department of 
Science and Technology (DST) (Women Scientist A Scheme (SR/WOSA/CS-31/2016)), Government of India for providing financial support. We thank Prof. Akhil R. Chakravarty for his help in conducting cytotoxicity studies at IISc Bangalore.

\section{References}

1. (a) Wang X, Wang X and Guo Z 2018 Metalinvolved theranostics: An emerging strategy for fighting Alzheimer's disease Coord. Chem. Rev. 362 72; (b) Mital $\mathrm{M}$ and Zoira Z 2018 Biological applications of $\mathrm{Ru}(\mathrm{II})$ polypyridyl complexes Coord. Chem. Rev. 375 434; (c) Rosenberg B, VanCamp L and Krigas T 1965 Inhibition of cell division in Escherichia coli by electrolysis products from a platinum electrode Nature 205698

2. Zamora A, Vigueras G, Rodríguez V, Santana M D and Ruiz J 2018 Cyclometalated iridium(III) luminescent complexes in therapy and phototherapy Coord. Chem. Rev. 36034

3. (a) Marzenell P, Hagen H, Sellner L, Zenz T, Grinyte R, Pavlov V, Daum S and Mokhir A 2015 Aminoferrocenebased prodrugs and their effects on human normal and cancer cells as well as bacterial cells J. Med. Chem. 56 6935; (b) Reshetnikov V, Daum S and Mokhir A 2017 Cancer-specific, intracellular, reductive activation of anticancer Pt prodrugs Chem. Eur. J. 23 5678; (c) Fricker S P 2007 Metal based drugs: from serendipity to design Dalton Trans. 434903

4. (a) Romero-Caneló I and Sadler P J 2013 Next generation metal anticancer complexes: Multi-targeting via redox modulation Inorg. Chem. 52 12276; (b) Malik A M, Dar A O, Gull P, Wani Y M and Hashmi A A 2018 Heterocyclic Schiff base transition metal complexes in antimicrobial and anticancer chemotherapy Med. Chem. Comm. 9409

5. (a) Farrer N J, Salassa L and Sadler P J 2009 Photoactivated chemotherapy (PACT): The potential of excited-state d-block metals in medicine Dalton Trans. 48 10690; (b) Zhang P and Sadler P J 2017 Redoxactive metal complexes for anticancer therapy Eur. J. Inorg. Chem. 2017 1541; (c) Lakshmi S S, Geetha K, Gayathri M and Shanmugan G 2016 Synthesis, crystal structures, spectroscopic characterization and in vitro antidiabetic studies of new Schiff base Copper(II) complexes J. Chem. Sci. 1281095

6. Mion G, Mari C, Da Ros T, Rubbiani R, Gasser G and Gianferrara T 2017 Towards the synthesis of new tumour targeting photosensitizers for photodynamic therapy and imagining applications Chemistry Select 2190

7. Bonnet R 2000 Chemical Aspects of Photodynamic Therapy (London: Gordon \& Breach) p. 57

8. Celli J P, Spring B Q, Rizvi I, Evans C L, Samkoe K S, Verma S, Pogue B W and Hasan T 2010 Imaging and photodynamic therapy: Mechanisms, monitoring, and optimization Chem. Rev. 1102795

9. (a) Knoll J D and Turro C 2015 Control and utilization of ruthenium and rhodium metal complex excited state for photoactivated cancer therapy Coord. Chem. Rev. 282283 110; (b) Dolmans D E J G J, Fukumura D and Jain
R K 2003 Photodynamic therapy for cancer Nat. Rev. Cancer 3380

10. (a) Kou J, Dou D and Yang L 2017 Porphyrin photosensitizers in photodynamic therapy and its applications Oncotarget 8 81591; (b) Jayaram DT, Ramos-Romero S, Shankar B H, Garrido C, Rubio N, Sanchez-Cid L, Gómez S B, Blanco J and Ramaiah D 2016 In vitro and in vivo demonstration of photodynamic activity and cytoplasm imaging through TPE nanoparticles ACS Chem. Biol. 11104

11. Joyce L E, Aguirre J D, Angeles-Boza A M, Chouai A, Fu P K L K R and Turro C 2010 Photophysical properties, DNA photocleavage, and photocytotoxicity of a series of dppndirhodium(II,II) Complexes Inorg. Chem. 495371

12. Heinemann F, Karges J and Gasser G 2017 Critical overview of the use of Ru(II) polypyridyl complexes as photosensitizers in one-photon and two-photon photodynamic therapy Acc. Chem. Res. 502727

13. Mari C, Pierroz V, Ferrari S and Gasser G 2015 Combination of $\mathrm{Ru}(\mathrm{II})$ complexes and light: new frontiers in cancer therapy Chem. Sci. 62660

14. Raza M K, Gautam S, Garai A, Mitra K, Kondaiah P and Chakravarty A R 2017 Monofunctional BODIPY-appended imidazoplatin for cellular imaging and mitochondria-targeted photocytotoxicity Inorg. Chem. 56 11019; (b) Gupta T, Patra K A, Dhar S, Nethaji M and Chakravarty R A 2005 Effect of copper-sulfur bond on the DNA photo-cleavage activity of 2-(methylthio)ethylpyridine-2-carbaldimine copper(II) complexes J. Chem. Sci. 117123

15. Zhang K Y, Ka-Shun Tso K, Louie M -W, Liu H -W and Lo K K-W 2013 A phosphorescent rhenium(I) tricarbonyl polypyridine complex appended with a fructose pendant that exhibits photocytotoxicity and enhanced uptake by breast cancer cells Organometallics 325098

16. Szaciłowski K, Macyk W, Drzewiecka-Matuszek A, Brindell M and Stochel G 2005 Bioinorganic photochemistry: Frontiers and mechanisms Chem. Rev. 105 2647

17. (a) Basu U, Khan I, Hussain A, Kondaiah P and Chakravarty A R 2012 Photodynamic effect in nearIR light by a remarkably photocytotoxiciron(III) cellular imaging agent Angew. Chem. Int. Ed. 51 2658; (b) Sarkar T, Banerjee S and Hussain A 2015 Significant photocytotoxic effect of an iron(III) complex of a Schiff base ligand derived from vitamin B6 and thiosemicarbazide in visible light $R S C A d v .5$ 29276; (c) Banerjee S, Dixit A, Maheswaramma S K, Maity B, Mukherjee S, Kumar A, Karande A and Chakravarty A R 2016 Photocytotoxic ternary copper(II) complexes of histamine Schiff base and pyridyl ligands J. Chem. Sci. 128165

18. Banerjee S and Chakravarty A R 2015 Metal complexes of curcumin for cellular imaging, targeting, and photoinduced anticancer activity Acc. Chem. Res. 482075

19. (a) Musib D, Banerjee S, Garai A, Soraisam U and Roy M 2018 Synthesis, theory and in vitro photodynamic activities of new copper(II)-histidinito complexes Chemistry Select 3 2767; (b) Mukherjee N, Podder S, Mitra K, Majumdar S, Nandi D and Chakravarty A R 2018 Targeted photodynamic therapy in visible light using BODIPY-appended copper(II) complexes of a vitamin B Schiff base Dalton Trans. 47 823; (c) Mukherjee 
N, Podder S, Banerjee S, Majumdar S, Nandi D and Chakravarty A R 2016 Targeted photocytotoxicity by copper(II) complexes having vitamin B6 and photoactive acridine moieties Eur. J. Med. Chem. 122 497; (d) Garai A, Pant I, Bhattacharyya A, Kondaiah P and Chakravarty A R 2017 Mitochondria-targeted anticancer activity of BODIPY-appended iron(III) catecholates in red light ChemistrySelect 2 11686; (e) Musib D, Raza M K, Kundu S and Roy M 2018 Modulating in vitro photodynamic activities of copper(II) complexes Eur. J. Inorg. Chem. 2018 2011; (f) Goswami T K, Chakravarthi B V S K, Roy M, Karande A A and Chakravarty A R 2011 Ferrocene-conjugated L-tryptophan copper(II) complexes of phenanthroline bases showing DNA photocleavage activity and cytotoxicity Inorg. Chem. 50 8452

20. Bhattacharyya A, Dixit A, Banerjee S, Roy B, Kumar A, Karande A A and Chakravarty A R 2016 BODIPY appended copper (II) complexes for cellular imaging and singlet oxygen mediated anticancer activity in visible light RSC Adv. 6104474

21. Bhattacharyya U, Kumar B, Garai A, Bhattacharyya A, Kumar A, Banerjee S, Kondaiah P and Chakravarty A R 2017 Curcumin drug stabilized in oxidovanadium(IV)BODIPY conjugates for mitochondria-targeted photocytotoxicity Inorg. Chem. 5612457

22. (a) Saha S, Patra A K, Nethaji M and Chakravarty A R 2007 Ternary iron(III) complex showing photocleavage of DNA in the PDT window Inorg. Chem. 46; (b) Saha S, Majumdar R, Roy M, Dighe R R and Chakravarty A R 2009 An iron complex of dipyridophenazine as a potent photocytotoxicagent in the visible light Inorg. Chem. 48 2652; (c) Sarkar T, Butcher R J, Banerjee S, Mukherjee $S$ and Hussain A 2016 Visible light-induced cytotoxicity of a dinuclear iron(III) complex of curcumin with lowmicromolar $\mathrm{IC}_{50}$ value in cancer cells Inorg. Chim. Acta 4398

23. (a) Roy M, Bhowmick T, Santhanagopal R, Ramakumar S and Chakravarty A R 2009 Photo-induced doublestrand DNA and site-specific protein cleavage activity of L-histidine ( $\mu$-oxo)diiron(III) complexes of heterocyclic bases Dalton Trans. 24 4671; (b) Roy M, Bhowmick T, Ramakumar S, Nethaji M and Chakravarty A R 2008 Double-strand DNA cleavage from photodecarboxylation of ( $\mu$-oxo)diiron(III) L-histidine complex in visible light Dalton Trans. 27 3542; (c) Roy M, Santhanagopal R and Chakravarty A R 2009 DNA binding and oxidative DNA cleavage activity of ( $\mu$ - oxo)diiron(III) complexes in visible light Dalton Trans. 01024

24. Chanu S B, Banerjee S and Roy M 2017 Potent anticancer activity of photo-activated oxo-bridged diiron(III) complexes Eur. J. Med. Chem. 125816
25. Perrin D D, Armarego W L F and Perrin D R 1980 Purification of Laboratory Chemicals (Oxford: Pergamon)

26. Gazi S and Ananthakrishnan R 2012 Semi-quantitative determination of hydroxyl radicals by benzoic acid hydroxylation. An analytical methodology for photofentonsystems Curr. Anal. Chem. 814

27. Gazi S, Rajakumar A and Singh N D P 2010 Photodegradation of organic dyes in the presence of $\mathrm{Fe}(\mathrm{III})$-salen complex and $\mathrm{H}_{2} \mathrm{O}_{2}$ under visible light irradiation J. Hazard. Mater. 183894

28. Begum M S A, Saha S, Nethaji M and Chakravarty A R 2010 Iron(III) Schiff base complexes of arginine and lysine as netropsin mimics showing AT-selective DNA binding and photonuclease activity J. Inorg. Biochem. 104477

29. Zamanifar E and Farzane F 2011 Immobilized vanadium amino acid Schiff base complexon Al-MCM-41 as catalyst for the epoxidation of allyl alcohols Reac. Kinet. Mech. Catal. 104197

30. Goswami T K, Chakravarthi B V S K, Roy M, Karande A A and Chakravarty A R 2011 Ferrocene-conjugated L-tryptophan copper(II) complexes of phenanthroline bases showing DNA photocleavage activity and cytotoxicity Inorg. Chem. 508452

31. Nakamoto K 2008 Infrared and Raman Spectra of Inorganic and Coordination Compounds: Part A: Theory and Applications in Inorganic Chemistry $6^{\text {th }}$ edn. (Location: John Wiley) p. 432

32. Frisch M J, Trucks G W and Schlegel H B 2009 Gaussian 09, Revision A. 1, Gaussian (Wallingford: USA)

33. Qu Y, Han B, Yu Y, Yao W, Bose S, Karlan B Y, Giuliano A E and Cui X 2015 Evaluation of MCF10A as a reliable model for normal human mammary epithelial cells PlosOne 10 e0131285

34. Wang H and Joseph J A 1999 Quantifying cellular oxidative stress by dichlorofluorescein assay using microplate reader Free Radicals Biol. Med. 27612

35. Manfred K Eberhardt and Colina R 1988 The reaction of copper(I)-oxygen and copper(II)-ascorbic acid-oxygen with dimethyl sulfoxide. The effect of solvent J. Org. Chem. 531071

36. Wang Z, Guo Y, Liu Z, Feng X, Chen Y and Tao T 2015 Catechin as a new improving agent for a photo-Fentonlike system at near-neutral $\mathrm{pH}$ for the removal of inderal Photochem. Photobiol. Sci. 14473

37. (a) Rieger A M, Nelson K L, Konowalchuk J D and Barreda D R 2011 Modified annexin V/propidium iodide apoptosis assay for accurate assessment of cell death $J$. Vis. Exp. 50 2597; (b) Raza MK, Mitra K, Shettar A, Basu U, Kondaiah P and Chakravarty A R 2016 Photoactive platinum(ii) $\beta$-diketonates as dual action anticancer agents Dalton Trans. 4513234 